\title{
Learning Activities in Preschool Classrooms: Preferences of Preschool Teachers and Views of Parents
}

\author{
Ahmet Sami Konca* \\ Department of Early Childhood Education, Erciyes University, Kayseri, Turkey \\ ORCID: 0000-0002-6423-6608
}

Seden Demirtaş İlhan

Department of Early Childhood Education, Artvin Çoruh University, Artvin, Turkey ORCID: 0000-0003-2447-8482

Article history

Received:

02.01.2021

Received in revised form: 22.03.2021

Accepted:

25.03.2021

Key words:

Activities,

Early childhood education,

Teacher perspectives,

Parents
Early childhood teachers and their preferences are very important in order to apply a balanced curriculum in the early childhood education classroom. On the other hand, the views of parents play an important role in classroom implementations; although their views can sometimes create barriers for teachers, and sometimes teachers can be inspired by them. As a result, both teachers' preferences and parents' views need to be investigated in order to understand how they affect learning activities in early childhood education classrooms. With this purpose, this study aims to investigate preschool teachers' preferences and parents' views of learning activities applied in preschool classrooms through a case study. The study included 25 preschool teachers and 33 preschool children's parents. Data collection took the form of semi-structured interviews held with the preschool teachers and the parents of preschool children. The results of the study revealed that the preschool teachers mostly preferred art, mathematics, and literacy activities, whilst science, drama, and body movement activities were the least implemented types of activities in the early childhood classroom. On the other hand, language, literacy and body movement activities were considered most important activities by parents. Moreover, the needs of the children, products, and processes were the first three reasons behind the teachers' classroom activity preferences, whilst the teachers' self-confidence in applying the activities was the least influential factor in their activity preferences.

\section{Introduction}

It is accepted in the literature that early childhood education programs intend to improve the early skills of young children such as their motor, language, and social skills (Hains, Fowler, Schwartz, Kottwitz, \& Rosenkoetter, 1989; Hanley, Cammilleri, Tiger, \& Ingvarsson, 2007; Lin, Lawrence, \& Gorrell, 2003). Another attempt of the preschool education is to prepare young children for primary education by motivating them to learn and

\footnotetext{
*Correspondency: samikonca@erciyes.edu.tr
} 
acquire more complex skills. A positive disposition to learn can be developed by engaging children in satisfying early classroom experiences. Children's enjoyment of learning in the classroom is likely to be related to events, types of classroom activities, materials, social interactions, and effective instructional strategies (Cammilleri, Tiger, \& Ingvarsson, 2007). For this reason, classroom activities play an important role to the reach aim of the preschool education.

In Turkey, the purpose of early childhood education is defined as ensuring improvement in the physical, cognitive, and emotional skills of young children, and in fostering good habits through rich learning experiences as afforded by the Turkish national education system (Milli Eğitim Bakanlığg [Turkish Ministry of National Education, MoNE], 2013a). In order to achieve this purpose, the Turkish national Early Childhood Education Program was renewed in 2013. The new program aims to support all developmental areas of children in a balanced manner. Besides, the program underlines an eclectic feature in terms of targeting the permanence of learning based on scientific studies. The child-centered program prioritizes the development of a child's creativity by learning through play and discovery. Also, the program proposes the designing of learning environments as learning centers, providing daily life experiences within learning environments during the learning process, making adaptations for children with special needs, and undertaking multidimensional assessments. Unlike previous preschool education programs, the current program provides children with sophisticated support, attaching importance to cooperation with counselors as well as to family participation (MoNE, 2013a).

In order to achieve the purpose of early childhood education, the current Turkish national Early Childhood Education Program suggests a balanced curriculum including both passive and active learning activities, various activity types (e.g., Turkish language, mathematics, play, and alike), diverse interaction patterns and group work (small groups and large groups), and different activity areas (indoors and outdoors) for young children (MoNE, 2013a). The types of activities provided in the program include Turkish language, art, drama, music, movement, play, science, mathematics, literacy, and also some field trips; and each of these activities are widely described in the curriculum book. Examples of activity types are shown in Table 1.

Table 1. Curriculum activity types and examples (MoNE, 2013a)

\begin{tabular}{ll}
\hline Activity type & Definition \\
\hline \multirow{4}{*}{ Turkish language } & $\begin{array}{l}\text { are planned to ensure that children } \\
\text { speak Turkish correctly and well, to asking riddles, chatting, reading picture books, } \\
\text { improve their vocabulary and to interactive and shared reading, storytelling } \\
\text { increase their communication skills }\end{array}$ \\
\hline \multirow{4}{*}{ Art } & $\begin{array}{l}\text { enable children to solve problems, Creating collage and three-dimensional works } \\
\text { think both critically and solution- using various artistic techniques and residual } \\
\text { oriented by using their creativity and materials, cutting, tearing-gluing } \\
\text { imagination }\end{array}$ \\
\hline \multirow{4}{*}{ Drama } & $\begin{array}{l}\text { aim to help children learn by doing, Verbal and non-verbal communication methods, } \\
\text { supporting their development with animations } \\
\text { predetermined goals based on } \\
\text { expressing events }\end{array}$ \\
\hline \multirow{3}{*}{ Music } & $\begin{array}{l}\text { support the whole development of Listening and discriminating sound and music, } \\
\text { children, and positively affect their rhythm studies, breath and sound studies } \\
\text { musical development process }\end{array}$ \\
\hline
\end{tabular}




\begin{tabular}{|c|c|c|}
\hline Activity type & Definition & Examples \\
\hline Movement & $\begin{array}{l}\text { aim to contribute to the child's whole } \\
\text { development and self-care skills of the } \\
\text { child by improving their basic } \\
\text { movement skills }\end{array}$ & $\begin{array}{l}\text { Activities that improve body awareness, field } \\
\text { awareness, strength, speed, quickness, } \\
\text { flexibility, endurance, and coordination }\end{array}$ \\
\hline Science & $\begin{array}{l}\text { encourage children to pay attention, ask } \\
\text { questions, wonder, observe, research, } \\
\text { examine, and to discover }\end{array}$ & $\begin{array}{l}\text { Visiting natural environments, hiking, observing } \\
\text { nature, living and non-living things in nature, } \\
\text { informing about the value and protection of } \\
\text { creatures, collecting }\end{array}$ \\
\hline Mathematics & $\begin{array}{l}\text { aim to contribute to the cognitive } \\
\text { development of children, to give } \\
\text { children a positive attitude towards } \\
\text { mathematics }\end{array}$ & $\begin{array}{l}\text { Matching, grouping, pattern creation, ordering, } \\
\text { counting, addition-subtraction and graphic } \\
\text { preparation }\end{array}$ \\
\hline Literacy & $\begin{array}{l}\text { collective form of study in which } \\
\text { children are supported equally across } \\
\text { all areas }\end{array}$ & $\begin{array}{l}\text { Visual view studies, auditory view, phonological } \\
\text { awareness studies, attention and memory studies, } \\
\text { basic concept studies. }\end{array}$ \\
\hline Field trips & $\begin{array}{l}\text { aim to meet the direct and meaningful } \\
\text { learning needs of children through } \\
\text { research, problem solving, and through } \\
\text { observing events as they happen on the } \\
\text { spot }\end{array}$ & $\begin{array}{l}\text { Field trips to places such as a historical place in } \\
\text { the region, a museum, an artist's workshop }\end{array}$ \\
\hline
\end{tabular}

Although play is defined as a separate activity type in the official Turkish preschool program book, as a basic characteristic of the curriculum, each activity is designed as play-based by preschool teachers (MoNE, 2013b); hence, play activities are not considered as a separate activity type in the current study. According to the aforementioned program book, it is important that the time allotted to each type of activity should be set in a balanced way. Activities can be planned, prepared, and implemented individually. That said multiple types of activities can be brought together and integrated into classes. Activities can also be planned and implemented for individual child, or for small groups or larger groups. Teachers are also expected to carry out these activities in an outdoor environment wherever possible (MoNE, 2013a).

Preschool teachers have a significant role to play in the planning, implementation, and assessment of the preschool education program. Teachers not only add quality to the education process with their knowledge, skills, and attitudes, but they also help to increase the development of children by playing a role in their acquisition of behaviors within the education program according to the methods, techniques, and strategies they apply. Teachers are required to integrate and use the technical knowledge that they acquired during their academic training in education combined with their own personality traits and experience. The preschool education program considers that each child has different developmental and individual characteristics, and also different competencies at varying levels (Dağlığlu, 2008; Şahin, 2005). For this reason, early childhood teachers and their preferences are considered very important to be able to apply a balanced curriculum in the early childhood education classroom. On the other hand, the views of parents play an important role in classroom implementations and, whilst their views may sometimes create barriers for teachers, at times teachers can be inspired by from them. As a result, both teachers' preferences and parents' views need to be investigated in order to understand how they affect learning activities in early childhood education classrooms.

With this purpose, the current study aims to investigate preschool teachers' preferences and parents' views of learning activities that are applied in the preschool classroom. When the available literature was reviewed, no sample study was found to exist that investigated both 
the teachers' preferences and the parents' views regarding learning activities. However, one study, published by Ayvallı and Şimşek (2020), had conducted a survey study with the aim of revealing the types of activities carried out by preservice early childhood education teachers within their daily education course schedule with rank-order judgements. The results of Ayvallı and Şimşek's (2020) study showed that the participant preservice teachers allocated most of the in-class activities to artworks, whilst field trips were the least frequently conducted activity. Moreover, their findings indicated that the in-class activities that the preservice teachers mostly preferred to conduct were science activities, with the least preferred being literacy activities. In the scaling of their study's results, Ayvallı and Şimşek (2020) concluded that differences existed between the in-class activities that the preservice teachers actually conducted and the in-class activities that they said they preferred to conduct. When the international literature is examined, similar studies applied in different cultures areencountered . To cite an example, with the same purpose, the types of Jordanian preschool curriculum activities were assessed, and the results revealed that preschools emphasise academic experiences such as teaching children skills for reading and writing letters and some words in Arabic and English, as well as counting, and basic tenants of Islam, and do not focus as much on play time (Ahmad, Fayez, \& Al-Zboon, 2015). On the other hand, Jayasuriya, Williams, Edwards and Tandon (2016) examined parents' perception of preschool activities regarding outdoor activities in the United States and found that although parents place importance on academics for their pre-schoolers, they also value and in fact demand for more outdoor time than the 60 min per day. Also, it is stated in the study that parents do consider outdoor play an important part of their child's time for child care but are not engaged in conversations about this with teachers and staff. Although previous studies of parents have shown that when selecting early childhood experiences for their children, parents value confining activities and compliance with adult expectations, while they define play as for fun or amusement. This is compared to teachers who also value play for cognitive and social development. More recent studies highlighted the benefit physical activity has on cognitive development during early childhood and supported the need to consider outdoor and physically active play areas as important for learning. Therefore, cultures and recent developments have influence on both parents 'views and teachers' preferences of classroom activities.

In the study of Saçkes (2013), the researcher took into consideration both the children's parents' views as well as those of early childhood education teachers' views regarding the priorities of developmental areas targeted in the Turkish preschool education program developed for children aged 36-72 months. According to the results, the views of the parents' regarding the priorities of the development areas defined in the preschool education program varied depending on their socioeconomic level, gender, and the age of their children. The results of the research also showed that a significant consistency existed between the views of the parents and the teachers regarding the priorities of development areas, and that the teachers prioritized psychomotor development more than the parents did. Another study regarding parents' expectations from preschool education conducted by Şahin, Sak and Şahin (2013) revealed that parents stressed various expectations related to the development of their children. Parents mostly prioritise social development and school readiness of their children so, activities which improve social development of their children are of great importance for parents. With these themes emanating from the literature review, the current study aimed to address the following research questions:

(1) What are the preschool teachers' preferences of learning activities applied in preschool classrooms? 
(2) What factors influence preschool teachers' preferences of learning activities applied in preschool classrooms?

(3) What are the parents' views of learning activities applied in preschool classrooms?

\section{Methodology}

This qualitative case study aimed to investigate preschool teachers' preferences and parents' perceptions of learning activities applied in preschool classrooms. This was a descriptive exploratory study that used a convenience sample to gather information within the scope of the study. The teachers' preferences of activity types and how they decided which activities to apply were questioned in this study. Additionally, the importance of the activity type to the parents, and what types of activities implemented in the preschool classrooms satisfy the parents were also examined.

\section{Participants}

The study included 25 preschool teachers and 33 parents of preschool children. Demographic information of the participants is presented in Table 2, in which it can be seen that while 20 teachers in the current study were female $(80.0 \%)$, five were male $(20.0 \%)$. The age of the teachers varied from 30 to 58 years old, and the mean age was 41.83 years, with 5.95 standard deviation. The minimum teaching experience of the participant teachers was 6 years, whilst the maximum was 30 years. The mean of the teachers' experience was 17.80 years $(S D=5.40)$.

Table 2. Participant Demographic Information

\begin{tabular}{llc}
\hline Variables & $n$ & $\%$ \\
\hline Preschool Teachers $(n=25)$ & & 80.0 \\
Gender & 20 & 20.0 \\
$\quad$ Female & 5 & \\
$\quad$ Male & $41.83 \pm 5.95(\min 30, \max 58)$ \\
Age (years) & $17.80 \pm 5.40(\min 6, \max 30)$ \\
Experience in the field (years) & & 87.9 \\
Parents $(n=33)$ & & 12.1 \\
Gender & 29 & 24.2 \\
$\quad$ Female & 4 & 45.5 \\
$\quad$ Male & & 30.3 \\
Educational level & & \\
$\quad$ Elementary school & & \\
$\quad$ High school & & \\
$\quad$ University & 15 & 10 \\
Age (years) & $34.64 \pm 5.33(\min 26, \max 44)$ \\
\hline
\end{tabular}

As can be seen from Table 2, both male and female teachers were included in the study group. The experience in the field of the teachers had a wide range. On the other hand, mean of the experience in the field was relatively high.

\section{Data Collection and Analysis}

The data was collected using semi-structured interviews that were held with the participant preschool teachers and the parents of preschool children. Questions included in the interviews with the teachers were based on (i) their demographic information, (ii) the types of 
activities conducted in their preschool classrooms, and (iii) the reasons for selecting those activities. The main question directed to teachers was "What kind of activities do you conduct in your classroom and why do you choose those activities?". For the children's parents, the interview questions posed concerned (i) their demographic information, and (ii) what in-class activities they deemed important. The parents were asked to answer, "Which in-class activities are important to you?". The face-to-face interviews were audio-recorded and then the recordings transcribed verbatim into textual format.

Lincoln and Guba's (1985) coding procedure was applied in the analysis of the collected data. First, a basic coding list was created. Then, as new codes emerged during the analysis process, these were added to the initial coding list. Additionally, some codes were combined or separated in line with relationships established between the various concepts. In terms of the validity of the data analysis procedure, some of the participants enrolled as informant, with their role being to help raise awareness of and resolve any issues pertaining to the meaning of the collected data.

Ethical issues were taken into consideration throughout the study according to the Ethical Code for Early Childhood Researchers (European Early Childhood Research Association, 2015) and all the necessary permissions were obtained from the legal bodies prior to carrying out the study. An informed consent form was provided to both the participant teachers and parents at the start of the data collection, and all of the participants voluntarily engaged in the interviews. The collected data was solely used for the purposes of conducting this research and was not shared with any third party. Moreover, pseudonyms were used to ensure anonymity of the participants in the reporting of the collected data.

\section{Results}

The current study focused on preschool teachers' preferences of in-class activities, and parents' views on the activities implemented within the early childhood classrooms. Table 3 presents the activity preferences according to the preschool teachers' answers, listed from the most frequently applied in the classroom to the least. The results revealed that the preschool teachers implemented different types of activities in their classrooms.

Table 3. Preschool Teachers' Preferences of Activities

\begin{tabular}{ll}
\hline Activity & $f$ \\
\hline Art & 20 \\
Literacy & 12 \\
Mathematics & 12 \\
Drama & 10 \\
Music & 10 \\
Language & 9 \\
Science/ nature & 9 \\
Body movement & 7 \\
\hline
\end{tabular}

As can be seen from Table 3, art $(f=20)$ literacy $(f=12)$, and mathematics $(f=12)$ were the three activities most frequently implemented by the teachers. On the other hand, music and drama $(f=10)$, science and language $(f=9)$, and body movement $(f=7)$ were reported less than other activities by the teachers. 
The results of the current study also presented the preschool teachers' definition of their mostly preferred activities, and some of the examples given to the most preferred activities were as follows:

Teacher 24, who preferred to use art, science, and math activities in the classroom, talked about art activities as, "In art activities, children can show their learning in creative ways. Art activities include drawings, free collage and recycling studies, and in that way the children produce a product." On the other hand, in defining an art activity, Teacher 25 said it "...can be organized on any branch of art like performance and visual arts."

Teacher 23, who preferred mathematics activities, explained understanding mathematics activities as, "All types of activities in which children encounter mathematics concepts and learn about mathematics abilities like counting and arithmetic."

Table 4. Factors Influencing Teachers' Preferences of Activities $(n=22)$

\begin{tabular}{lll}
\hline Factor & $f$ & Explanation \\
\hline Product & 23 & Materials, artworks, drawings derived from activity \\
Process & 19 & $\begin{array}{l}\text { Playtime, peer interaction, context of activity } \\
\text { Children's acquiring concepts, supporting language and social } \\
\text { skills } \\
\text { Needs of children }\end{array}$ \\
Demand of parent & 76 & $\begin{array}{l}\text { Parents' asking for more play or outdoor activities } \\
\text { Teachers' content knowledge required for an activity, prior } \\
\text { experience }\end{array}$ \\
Self-confidence of teacher & 5 &
\end{tabular}

The teachers were also asked about the factors influenced their preferences for certain activities, and the results are presented in Table 4. First, producing a product $(f=23)$ was revealed as the most influencing factor in terms of the teachers' activity preferences. Next, the teachers prioritized the process of the activity $(f=19)$ whilst deciding on which activity to employ. More than half of the teachers emphasized the needs of the children $(f=16)$ as an influencing factor on their preferences. On the other hand, the demands and expectations of the parents $(f=7)$ were shown as being fourth on the list of factors influencing teachers' activity preferences. Finally, the teachers' own self-confidence $(f=5)$ was the factor that the teachers took into account the least whilst choosing an activity.

The teachers' answers regarding the factors that influenced their preferences included the following statements:

Teacher 24, who was one of the preschool teachers that indicated the product as being the most influential factor in their preference of classroom activities said, "As the products inform teachers about the progress of children, I prefer creating a product at the end of an activity." Also, Teacher 14 emphasized the influence of the product by saying that, "Practicality, usability, and producing tangible products make an activity preferable." Teacher 18, who was one of the teachers who said they were influenced by the product factor, also emphasized the needs of children by saying, "Getting a qualified product at the end of the activity process and also the developmental needs of the children are the most influential factors in my activity preferences." 
Table 5. Importance of Activities for Parents $(n=33)$

\begin{tabular}{ll}
\hline Activity & $f$ \\
\hline Language & 18 \\
Literacy & 16 \\
Body movement & 14 \\
Mathematics & 13 \\
Art & 12 \\
Science/ nature & 11 \\
Drama & 9 \\
Music & 8 \\
\hline
\end{tabular}

The parents' views regarding the activities they considered important from the most important to the least important are presented in Table 5. The parents reported language $(f=18)$, literacy $(f=16)$, and body movement $(f=14)$ activities as the three most important activities in terms of the development and learning of their children. At the other end, science/nature $(f=11)$, drama $(f=9)$, and music $(f=8)$ activities were noted as the least important activities according to the parents.

Some examples from the parents' answers regarding the importance of the in-class activities included the following statements:

Parent 31 was one of the parents who gave importance to language and literacy activities, and stated that, "I think all literacy and language activities that prepare my child for primary school are important, and that these activities should be implemented frequently." On the other hand, Parent 33 emphasized the importance of art activities by saying that, "...activities including drawing and cutting-gluing tasks are the most important for children as they support their small muscle growth."

\section{Discussion}

This study focused on activities implemented within early childhood classrooms according to the perspectives of preschool teachers and children's parents. Within the scope of this research, the teachers' in-class activity preferences and how they chose those activities were investigated. Then, the parents' views on the implemented activities in early childhood education were examined. This section presents interpretations of the findings, suggestions for policy making and practice, also pointing to the limitations of the study.

The results revealed that the preschool teachers mostly preferred art, mathematics, and literacy activities; whereas, science, drama, and body movement activities were the least implemented in the early childhood classrooms. The preschool teachers are responsible for both choosing and implementing a number of elements within the educational process of the early childhood classroom. Therefore, their conceptualizations of the activities they implement can be highly influential on the children's learning and development. As a matter of fact, teachers' practices are important as these can significantly influence children's play behaviors; for example, Özdemir (2014) reported that children usually prefer to engage in art activities during their free play time. It was emphasized that supporting children's developmental areas across the spectrum is vital, and that the development should start from the early years (Gardner, 1969). Therefore, all the needs of children should be taken into consideration in their education (Miller, 2000). 
Several studies have documented the differing habits and perspectives of teachers. It has been reported that preschool teachers give importance to the activities which aim to improve children's psychomotor skills, as those skills are mostly accepted as a predictor of readiness of preschool children to attend elementary education (Dereli, 2012; Dockett \& Perry, 2004). Saçkes (2013) found that early childhood teachers underlined the importance of supporting all developmental areas of young children. However, the current study revealed that there are differences between the activity types preschool teachers implemented; for example, the teachers frequently engaged children in art activities. Ayvallı and Şimşek (2020) stated that preservice early childhood teachers mostly offered artworks during observation of their field experience during their final year of their bachelors' education. On the other hand, the current study found that certain activities were less frequently implemented in the classrooms, such as science activities. Although early childhood teachers believe in the importance of science activities (Öztürk Y1lmaztekin \& Erden, 2017), they may overlook science activities as they feel pressured to spend school time teaching mostly literacy and language (Greenfield et al., 2009). In addition, the teachers may see art activities as more easily measured activities. Öztürk Y1lmaztekin and Erden (2017) also reported that teachers integrate art activities as an assessment tool within science activities as a means to evaluating the children's learning based on their art products.

The current study revealed that the needs of children, creating a product at the end, and a focus on process were the three primary reasons behind teachers' activity preferences. In addition, the teachers' self-confidence in applying a certain type of activity was the least influential factor when it came to choosing an activity. The MoNE (2013a) suggests that teachers implement design activities in order to meet the needs of the children in their class, and to focus on the process rather than the product. However, as was previously emphasized, the preschool teachers in the current study mostly implemented art activities; therefore, they may see the end product as a motivation for implementing art activities. In the literature, Ebbeck, Yim, and Warrier (2019) reported physical and human resources as an influencing factor in teachers' practices. According to Güler and Demir (2016), parents' and school administrators' expectations from teachers also play a role in their decisions regarding classroom activities. Bröstrom et al. (2015) compared teachers' views from six different European countries. They reported that teachers' practices were highly influenced by the local culture of each country. Therefore, teachers' decisions on which activity to introduce in the classroom may also be explained by the culture of the society.

When it comes to parents' views on the activities their children take part in within the preschool classroom, literacy, body movement, and language activities were considered to be the most important. However, art, drama, and music activities were seen as the least important activity types. Similarly, there were differences obnserved in the literature between the results of studies regarding parents' outlooks on classroom-based activities. Through engaging children into early childhood education, parents may aim to improve the academic achievement of their young children, and/or to support their children's social behaviors such as self-confidence (Brannon, 2005). Saçkes (2013) reported that parents prioritized self-care, language, and social-emotional skills of children. Ceylan (2019) reported on parents' expectations of activities in which children were physically active. On the other hand, Bay, Bahçıvan, and Kalay (2018) underlined parents' demands for more social activities. Various studies also reported how parents emphasized activities that included peer interaction supporting social skills as positive outcomes of early childhood education (Konca, 2020; Sak, Şahin-Sak, Öneren-Şendil, \& Taşkın, 2020). In a parallel manner, Ceylan (2019) underlined that social activities that schools offer can even influence parents' choice of school. Yaka, 
Yalçin, and Denizli (2014) emphasized that the socioeconomic background of families can affect their views as regards implementations in early childhood institutions. Whilst parents with a low socioeconomic status considered academic values as the most important, parents from a high socioeconomic background accepted personal and social values as the most important outcome of early childhood education. It should also be noted that in the current study, the parents' views were not found to be consistent viz. with differing views held on the types of activity most valued. This may refer to the situation that parents are not all that familiar with the roles of activities in terms of the development of children.

\section{Conclusion and Limitations}

The current study underlined the importance of both parents' and teachers' views regarding early childhood activities. The results of the study may be taken into consideration during the development and modification of early childhood curricula. $\mathrm{Ng}$, Fisher, $\mathrm{Au}$, and Lo (2020) underlined the cohesion between teachers' and parents' consideration of early childhood education. The harmony between parents and teachers is important for supporting children in the home setting in parallel with school. When teachers' and parents' expectations and practice align, this may help to improve and positively influence the success of a child's early education.

Teachers' beliefs regarding the contents of an early childhood education program can create differences between the goals of the educational program and the actual classroom practices (Kırkgöz, 2008). Beside the beliefs of teachers, as the current study revealed, the selfconfidence of teachers, the needs of the children, and also meeting the demands of the parents each has an effect on classroom practices. For this reason, further studies should be conducted in order to inquire into and unearth the factors affecting classroom practices of preschool teachers. Additionally, more studies may help early childhood researchers to understand how parents perceive early childhood education, and whether their expectations are in fact suited to the curricula in force.

The current study has several limitations based on the data collection procedure. First, only a small sample of preschool teachers and parents were included in the study. Therefore, additional research using much larger samples would be necessary in order to understand the general tendency of teachers' activity preferences and the parents' corresponding views. Another limitation of the current study also relates to the data collection method, which was interview-based and to its being reliant upon the responses of the participants. In further studies, observations including preschool teachers' classroom practices could be included as an additional method of data collection.

\section{References}

Ahmad, J., Fayez, M., \& Al-Zboon, E. K. (2015). The type of curriculum activities implemented in Jordanian preschools. Early child development and care, 185(5), 807823. https://doi.org/10.1080/03004430.2014.958482

Ayvallı, M., \& Şimşek, E. E. (2020). Okul öncesi öğretmen adaylarının sınıf içi uygulamalarında yer verdikleri etkinlik türlerinin sıralama yargıları kanunuyla ölçeklenmesi [Pre-service early childhood teachers' ranking of in-classroom activities]. Journal of Education and New Approaches, 3(1), 1-15. https://dergipark. org.tr/tr/pub/jena/issue/55266/681648

Bay, D. N., Bahçıvan, E., \& Kalay, B. (2018). Okul öncesinde okul aile işbirliğine yönelik ailelerin ve öğretmenlerin görüşleri [Expectations of parents and teachers for school- 
family collaboration at pre-school]. Usak University Educational Research Journal, 4(3), 58-82. https://dergipark.org.tr/tr/pub/usakead/issue/ 38812/461787

Brannon, D. (2005). Full- or half-day kindergarten: What parents pick- and why. Education Digest, 70(8), 57-62. http://www.eddigest.com/sub.php?page=9

Broström, S., Sandberg, A., Johansson, I., Margetts, K., Nyland, B., Frøkjær, T.,...Vrinioti, K. (2015). Preschool teachers' views on children's learning: an international perspective. Early Child Development and Care, 185(5), 824-847. https://doi.org/10.1080/ 03004430.2014 .958483

Ceylan, R. (2019). Ebeveynlerin okul öncesi kurumu hakkındaki görüşleri: Tercih sebepleri, beklentileri ve memnuniyetleri [Parents' views about center-based child care: their preferences, expectations and satisfactions]. Electronic Journal of Social Sciences, 18(70), 497-517. https://doi.org/10.17755/esosder.414788

Dağlığlu, E. (2008). Ülkemizde okul öncesi eğitim [Early childhood education in our country]. Journal of View on Education, 12, 45-53. https://www.ebs.org.tr/ebs_files/files/ yayinlarimiz/Egitime_Bakis_12_Sayi.pdf

Dereli, E. (2012). Okulöncesi öğretmenleri ile ilköğretim birinci sınıf öğretmenlerinin ilköğretime hazırlık süreci ile ilgili görüşlerinin karşılaştırılarak incelenmesi [The views of preschool teachers and primary school teachers about primary school process of transition to primary school]. Journal of Academic Perspective, 30, 1-20. https://www.akademikbakis.org/file/30.pdf

Dockett, S., \& Perry, B. (2004). Starting school: Perspectives of Australian children, parents and educators. Journal of Early Childhood Research, 2(2), 171-189. https://doi.org/10.1177/1476718x04042976

Ebbeck, M., Yim, H. Y. B., \& Warrier, S. (2019). Early childhood teachers' views and teaching practices in outdoor play with young children in Singapore. Early Childhood Education Journal, 47(3), 265-273. https://doi.org/10.1007/s10643-018-00924-2

European Early Childhood Research Association. (2015). EECERA Ethical Code for Early Childhood Researchers. Retrieved from: https://www.eecera.org/wpcontent/uploads/2016/07/EECERA-Ethical-Code.pdf

Gardner, D. E. M. (1969). Susan Isaacs: The First Biography. London: Methuen. https://doi.org/10.4324/9781315175355

Greenfield, D. B., Jirout, J., Dominguez, X., Greenberg, A., Maier, M., \& Fuccillo, J. (2009). Science in the preschool classroom: A programmatic research agenda to improve science readiness. Early Education and Development, 20(2), 238-264. https://doi.org/10.1080/10409280802595441

Güler, B. İ., \& Demir, E. (2016). Okul öncesi ögretmenlerinin riskli oyunlara yönelik görüs ve algilari [Opinions and perceptions of preschool teachers towards risky play]. Journal of Special Education, 17(2), 97-116. https://doi.org/10.21565/ozelegitimdergisi.246484

Hains, A. H., Fowler, S. A., Schwartz, I. S., Kottwitz, E., \& Rosenkoetter, S. (1989). A comparison of preschool and kindergarten teacher expectations for school readiness. Early Childhood Research Quarterly, 4(1), 75-88. https://doi.org/10.1016/s08852006(89)90090-2

Hanley, G. P., Cammilleri, A. P., Tiger, J. H., \& Ingvarsson, E. T. (2007). A method for describing preschoolers' activity preferences. Journal of Applied Behavior Analysis, 40(4), 603-618. https://doi.org/10.1901/jaba.2007.603-618

Jayasuriya, A., Williams, M., Edwards, T., \& Tandon, P. (2016). Parents' perceptions of preschool activities: exploring outdoor play. Early education and development, 27(7), 1004-1017. https://doi.org/10.1080/10409289.2016.1156989 
Kırkgöz, Y. (2008). Curriculum innovation in Turkish primary education. Asia-Pacific Journal of Teacher Education,36(4), 309-322. https://doi.org/10.1057/ 9780230347823_14

Konca, A. S. (2020). Velilerin okul öncesi eğitim hakkında görüşlerinin incelenmesi [Parents' views about early childhood education]. Journal of Ahi Evran University Social Sciences Institution, 6(3), 892-902. https://doi.org/10.31592/aeusbed.804853

Lin, H. L., Lawrence, F. R., \& Gorrell, J. (2003). Kindergarten teachers' views of children's readiness for school. Early Childhood Research Quarterly, 18(2), 225-237. https://doi.org/10.1016/s0885-2006(03)00028-0

Lincoln, Y. S., \& Guba, E. G. (1985). Naturalistic inquiry. California: Sage Publications.

Miller, J. (2000). Education and the Soul: Toward a Spiritual Curriculum. New York: State University of New York.

Milli Eğitim Bakanlı̆̆ı. (2013a). Okul Öncesi Eğitim Programı [Early childhood education curriculum]. Ankara, Turkey: Milli Eğitim Basımevi. Retrieved August 28, 2015, from http://www.onceokuloncesi.com/okuloncesi_egitimprogrami.pdf.

Milli Eğitim Bakanlığı. (2013b). Okul Öncesi Ĕ̈itim Programı Etkinlik Kitabı [Early childhood education curriculum activity book]. Ankara, Turkey: Milli Eğitim Basımevi. Retrieved August 25, 2015, from http://anaokulu.cu.edu.tr/_ _/file/OOEP_2013_Etkinlik_Kitabi.pdf

Ng, D. T.-K., Fisher, J. W., Au, M. L., \& Lo, S. K. (2020). Parental perceptions of holistic early childhood education in Hong Kong. Educational Planning, 27(1), 49-60. https://isep.info/wp-content/uploads/2020/04/Vol27.Issue1_.pdf

Özdemir, S. (2014). 5-6 Yas Grubu Çocuklarin Serbest Zaman Etkinliklerindeki Oyun Ve Oyuncak Tercihlerinin İncelenmesi [Examining the games and toys choices of children aged 5 to 6 at their free time activities]. Journal of Educational Science, 2(2), 1-15. https://dergipark.org.tr/tr/pub/jedus/issue/16125/168707

Öztürk Y1lmaztekin, E., \& Erden, F. T. (2017). Investigating early childhood teachers' views on science teaching practices: the integration of science with visual art in early childhood settings. Early Child Development and Care, 187(7), 1194-1207. https://doi.org/10.1080/03004430.2016.1160899

Saçkes, M. (2013). Erken çocukluk eğitiminde önem verilmesi gereken gelişimsel alanlar: anne-baba ve öğretmen önceliklerinin karşılaştırılması [Priorities for developmental areas in early childhood education: a comparison of parents' and teachers' priorities]. Kuram ve Uygulamada Ĕ̈itim Bilimleri Dergisi, 13(3), 1675-1690. https://doi.org/10.12738/estp.2013.3.1634

Sahin, I. T., Sak, R., \& Tuncer, N. (2013). Comparison of Preschool and First Grade Teachers' Views about School Readiness. Educational Sciences: Theory and Practice, 13(3), 1708-1713. https://doi.org/10.12738/estp.2013.3.1665

Sak, R., Şahin-Sak, İ. T., Öneren-Şendil, Ç., \& Taşkın, N. (2020). Eğitim Paydaşlarının Okul Öncesi Eğitimin Zorunlu Olmasına İlişkin Görüşleri [Views of stakeholders' about compulsory preschool education]. Yaşadıkça Eğitim, 34(1), 58-78. https://doi.org/10.33308/26674874.2020341161

Şahin, E. (2005). Okulöncesi Eğitim Öğretmen Adayları ve Öğretmenleri İçin Uygulama Kilavuzu [Implementation book for preservice and in-service early childhood teachers]. Ankara, Turkey: Anı Publishing.

Yaka, Ş., Yalçin, D., \& Denizli, E. (2014). Okul öncesi eğitimde verilecek öncelikli değerlere ilişkin veli görüşleri [Parents' views on preferential values in preschool education]. Journal of Values Education, 12(28), 169-192. https://dergipark.org.tr/tr/ $\mathrm{pub} / \mathrm{ded} /$ issue/29170/312366 